\title{
Wakif Preferences In Selecting Cash Waqf: A Case of Badan Wakaf Indonesia at Yogyakarta City
}

\author{
Kurniawati Meylianingrum ${ }^{1}$, Muhammad Muhajir Aminy ${ }^{2}$, Mohd. Mizan Aslam ${ }^{3}$ \\ UIN Maulana Malik Ibrahim Malang ${ }^{1}$, Indonesia, UIN Mataram, Indonesia ${ }^{2}$, \\ Universiti Malaysia Perlis ${ }^{3}$ \\ meylianingrum@,uin-malang.ac.id $\mathrm{d}^{1}$, azeer.elkhawarizm@,uinmataram.ac.id ${ }^{2}$, \\ mohdmizan@gmail.com ${ }^{3}$
}

\begin{abstract}
Cash waqf is an Islamic financial instrument which recently is developed by most Muslim scholars. This Islamic financial instrument is believed to be one alternative to solicit social funds from people, other than zakat, with a purpose to gain sustainable benefits without reducing the amount of used fund.

Cash waqf is not similar to zakat that is a mandatory and an Islamic pillar for Muslims across the world. Cash waqf is a preferable (sunnah) that is encouraged to be carried out by Muslims to gain ceaseless reward from God. Muslims who spend their money for this Islamic charity have an awareness to do more kindness as a worship form to God.

This study aims to analyse the influence of four independent variables, namely religiosity, trust, service quality, and promotion factor on wakif decision to select cash waqf product in Badan Wakaf Indonesia region of Yogyakarta City. The findings showed a positive significant impact, simultaneously and partially, from all observed independent variables toward the dependent variable.

Another purpose of this study is to investigate a cash waqf management that is applied in the waqf institution. The duty of Badan Wakaf Indonesia as the waqf institution is only to supervise the nazhirs, waqf managers, regarding their cash waqf management. Badan Wakaf Indonesia indirectly collects and distributes all cash waqf through all its five nazhirs.
\end{abstract}

Keywords: Waqf, Cash Waqf, Wakif Preferences, Wakif Decision

\section{A. INTRODUCTION}

Waqf is a preferable (sunnah) Islamic charity in the religion of Islam. Nevertheless, this charity will be mandatory when it becomes a testament from the asset owner (Ab Rahman, 2009). Waqf is not only in the form of donating and providing a building, land, or other physical assets to people in order to obtain continuous rewards from God but also in the form of cash. Cash waqf plays a significant and important role in the economy as a new fiscal instrument which could be considered by the governments to enhance national welfare for their societies(Al Arif, 2012). This instrument has two

Received: August,I5 2020 - Revised: August,I8 2020 - Accepted: August, 262020

Occupuation: UIN Maulana Malik Ibrahim Malang ${ }^{1}$, IndonesiaUIN Mataram², Universiti Malaysia Perlis $^{3}$

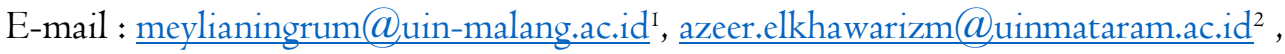
mohdmizan@gmail.com ${ }^{3}$ 
essential functions as a form of Islamic worship and a contributing Islamic tool to achieve global welfare.

Cash waqf in Indonesia has a vast potential to be solicited among Muslims population, reaching at 3 trillion rupiahs annually (Hasan, 2010). This amount is calculated with the following assumptions: I) most Muslims in middle-up class has a high awareness on giving Islamic charities like zakat, waqf, and the other forms, 2) the number of this Muslims class reached up to I0 million people with the average of monthly income varies from 500.000 to I0.000.000 rupiahs, and 3) the value of one cash waqf certificate is ranging from 5.000 to $\mathbf{1 0 0 . 0 0 0 ~ r u p i a h s . ~ T h i s ~ c a s h ~ w a q f ~ p o t e n t i a l ~ c a n ~ b e ~ a d d i t i o n a l ~}$ funds in an effort of eradicating poverty in the country if it is managed professionally by the appointed waqf institutions.

A Legal institution in Indonesia that has been mandated to collect waqf funds is Badan Wakaf Indonesia (Indonesian Awqaf Board). The duties of this institution are as follows: I) To help nazhir (waqf managers) developing their abilities and competences in managing waqf funds and assets, 2) To manage and develop waqf funds and assets in a national and international scale, 3) To approve the formal status changing of waqf funds and assets, 4) To discharge and replace the nazhir who manage waqf funds and assets, 5) To give acceptance on waqf funds and assets exchanging, 6) To give recommendations to the governments on waqf policies making(Aziz, 20I7).

Badan Wakaf Indonesia has several branches across provinces within Indonesia, including Daerah Istimewa Yogyakarta (Special Region of Yogyakarta). Badan Wakaf Indonesia branch Yogyakarta does not stand itself in collecting and distributing cash waqf. The process of both involves the nazhir (cash waqf managers) which have been permitted by Badan Wakaf Indonesia. At least I3 nazhir have been accepted and registered at Badan Wakaf Indonesia as parts of cash waqf management in the region.

Yogyakarta City as part of Special Region of Yogyakarta has five nazhir which has been appointed by Badan Wakaf Indonesia to be part of cash waqf management in the area. They are Badan Wakaf Uang Tunai Majelis Ulama Indonesia Daerah Istimewa Yogyakarta, KSP BMT Al-Ikhlas, KJKS BMT Beringharjo, BMI BMT Bina Ihsanul Fikri, and Dewan Masjid Indonesia Wilayah Daerah Istimewa Yogyakarta. Three of these nazhir which are Badan Wakaf Uang Tunai Majelis Ulama Indonesia, BMI BMT Bina Ihsanul Fikri, and Dewan Masjid Indonesia Wilayah Daerah Istimewa Yogyakarta have good reputation in collecting and distributing cash waqf. According to the annual report of cash waqf collection of Badan Wakaf Indonesia Wilayah Daerah Istimewa Yogyakarta, cash waqf which has been solicited within the year reaching at 899.960.000 rupiahs.

A tremendous amount of cash waqf collection is indicating a big interest of Muslim inhabitants, particularly in Yogyakarta City, to develop cash waqf product as an Islamic philanthropy instrument. This research paper is particularly keen to investigate factors which are driving the Muslims' interest in giving part of their money as cash waqf to be managed by the appointed nazhir.

\section{B. THEORETICAL}

\section{Religiosity}

In Islam, religiosity level can be reflected from the depth of a Muslim's knowledge, his beliefs, and way of performing worship that is obligated in the religion of Islam (Fitriyah, 2016). According to Glock and Rodney (1968) in (Maisur, Arifin, M. arfan, 2015), religiosity is an inner condition that is motivating a person to think, to behave, and to act in line with his religion's teachings and guide. 
Sukamto stated that a personality consists of four aspects: conscience, the nature of the heart, selfishness, and morals. All these aspects of personality have different functions, components, and work principles by themselves. Regardless of that condition, all of them are related eachothers and cannot be separated (Jalaluddin, 2012). Religion becomes a measurement tool for human being on their existence in the universe. Therefore, religion will involve mankinds into life problems in the world (Nottingham, 1985).

The indicators of human religiosity are ideological demention or to believe in religion, experiental dimension that encompasses self-experience on performing religious orders, intellectual involvement that relates to religious knowledges, ritual dimension that explains the level of a person performing worship and obligation in his religion, consequention dimension that measures how far someone's behaviours are encouraged by his religion's teachings in social lives (Maisur, Arifin, M. arfan, 2015). Omer (1992) stated that economic behaviour is determined by the level of someone's or people's faith. This behaviour will form tendency of consumption and production behaviour. Hence, this kind of perspective will influence saving behaviours(Maisur, Arifin, M. arfan, 2015). The influence will appear on someone's identities or characters and personal values that impacted on his way of consumption (Romdhoni, A. H., Ratnasari, 2018).

Waqf institution is an Islamic-based institution, thus religiosity should be implemented in all aspects as a form of obedience on religion and be applied in social lives (Romdhoni, A. H., Ratnasari, 2018).

\section{Service Quality}

Service quality is defined as a comparison between expected quality with actual quality received by the consumers (Tumbelaka, A., Kindangen, P., \& Kalangi, 2019). Service quality is described as a form of service resulted from the difference between consumer expectations and corporate abilities. A maximum service quality is not only able to make consumers comfortable with the service given by corporates, but also to encourage the consumers to repurchase corporate's products (Rahayu, 2018). Moenir (2010) as cited from (Rahayu, 2018) stated that a service is an activity carried out by a person or people based on material factors through systems, procedures, and specific methods in order to fulfill consumers interests. Service also can be defined as a totality of features and product characteristics depend on the ability to satisfy consumers' needs (Kotler, P., \& Keller, 2009).

Service is also an activity and something that can be offered by an institution or corporate in intangible forms to the other parts, and it does not belong to them. To measure how far service quality is able to influence the consumers, a representation of service quality is needed. This representation will be evaluated by the consumers based on service quality they have received. The evaluation can be carried out with a survey method directly to the specific consumers (Maisur, Arifin, M. arfan, 2015). Service needed by human being is categorized into two forms: personally physical service and administrative service given by a person to other organization members (Nurlaeli, 2017).

Basic concepts of service quality are divided into five categories as follows: tangible, reliability, responsiveness, assurance, and emphaty. Tangible is a corporate's ability to show its existence to the external parts. Reliability is a corporate ability to give services in accordance with its promises accurately. Responsiveness is a corporate willingness to help and to give fast and right services to its consumers with a clear information. Assurance is a guarantee of certainty of services given to the 
consumers. Emphaty is to give full and honest attention to the consumers with an effort to understand their expectation (Sarwita, 2019).

\section{Trust}

According to Mayer as cited from (Yulianti, R., Sangen, M., \& Rifani, 20I6), trust is a will of people to receive services from others in accordance with their expectation, regardless of the ability to monitor and to control. Trust is a willingness of corporate to depend on its business partners (Kotler, P., \& Keller, 2009). Trust is someone's belief on the others in exchanging process (Tajudin, M. H., \& Mulazid, 2017).

Trust is a confidence on the service providers that they are able to manage this component as a tool to strengthen long-term relationship with their customers in term of business cycle. Increasing of trust level between both parts will benefit for corporates for repurcashing products consideration by the customers (Dewi, W. S., Hasiolan, L. B., \& Minarsih, 2016). Element of trust depends on several factors: competency, integrity, honesty, and benevolence or kindness of corporates (Tajudin, M. H., \& Mulazid, 2017)(Pratiwi, N., \& Seminari, 2015). Trust involved willingness of someone to behave as common expectations by human being that the words, promises, or statements of others can be trusted (Murti, I., \& Santika, 2016).

\section{Promotion}

In an effort to increase their consumers, corporates highly need to carry out promotion activity. There are several factors to support this action. Promotion activity is influenced by a clear purpose of corporates. Promotion is in relation with several activities to influence consumers behaviour. Promotion is highly important for corporates in order to increase their consumers, because this activity will enable consumers to understand their products' specifications and characteristics offered in the market. Promotion is also an activity to influence consumers and to make products' supply and demand inside their targeted market. Promotion is not only a communication tool between corporates and consumers, but also an a tool to influence consumers for purchasing and repurchasing activity on products and services to fulfill their needs (Fahrudin, M. F., \& Yulianti, 20I5).

In marketing management studies, promotion policy is commonly divided into four activities: advertising, public relation, sales promotion, and personal selling (Husein, 2008). Advertising is a nonindividual communication an amount of money to carry out as the advertising fee through several media of publications carried out by corporates, institutions, non-profit organizations, and individuals. Advertising has functions to inform, persuade, make an impression, satisfy the will, and to communicate indirectly (Sarwita, 2019). Personal selling is an individual face-to-face interaction between products or services sellers and purchasers with a purpose to create, repair, dominate, and maintain exchanging relationship that might benefit for both parts (Sarwita, 2019). Public relation is defined as a function of management that gives an assessment on people's reaction, policy's identities, and procedures from individuals or organizations, and to carry out a program that would able to get people's attention and recognition. There are several changes on promotion strategy paradigms as the impact of technology changes in current conditions (Nurlaeli, 2017). 
Table I. Changes on Promotion Strategy Paradigms

\begin{tabular}{lll}
\hline Promotion Factors & Pre Technology Changes & Post Technology Changes \\
\hline Target & Massive & Users \\
\hline Purchasing frequency & One time only & Repeatedly \\
\hline Corporates' orientation & Manufacture/ Engineering & Brand marketing \\
\hline Type of communication & Verbal & Visual \\
\hline Differentiate by & Technology & Brand \\
\hline Competition level & Moderate & Agressive \\
\hline Production run & Simple & Complex/Customized \\
\hline Medium of communication & Televisions and newspapers & $\begin{array}{l}\text { Multimedia, Integrated } \\
\text { marketing communication }\end{array}$ \\
\hline
\end{tabular}

\section{Consumers Preferences}

Preferences can be defined as the most natural feeling, reliable, and comfortable in specific ways in behaving and experiencing something (Bayne, 2015). In other words, preferences are a broader human capacity which presents beforehand to behave and to think authentically, to help in the development and optimal performance as well (Linley, 2008).

The role of consumer preferences is to be an initiator, influencer, decider, purchaser, and user. Preferences are described as a consumer attitude on specific products or services and is intended to be an evaluation material. Meanwhile, Schiffman and Kanuk stated that attitude is an inner feeling which reflected someone's happiness, sadness, approval, or dislike on a specific object.

A company should understand well its consumer behaviours in order to promote its products (Chrysanthini, B., Sumarwan, U., \& Rifin, 2018). A well-established company can predict consumer response on its products and services it offered. Thus, the company might apply several strategies which increase products and services selling. Consumer preferences analysis is in strong relation with the assessment of consumer's satisfaction on products, services, even the company itself (Sumarwan, U., Noviandi, A., 2013).

Consumer preferences are highly important to help a company designing its marketing strategies in order to win the competitiveness with other companies within the market (Tumbelaka, A., Kindangen, P., \& Kalangi, 2019). Preferences knowledge in capitalist economics concept is different from the Islamic economics concept. Capitalist economics perceived consumer preferences only as a benefit for the company, while preferences in Islamic economics is intended to enhance economic welfare for society, equal distribution, and high commitment on fraternity (Marthon, P., \& Papaix, 2008).

Preferences in standard psychological theory are divided into eight parts as follows: I) extraversion, 2) sensing, 3) thinking, 4) judging, 5) introversion, 6) intuition, 7) feeling, and 8) perceiving (Bayne, 20I5). A wakif (waqf giver) is likened to a company's consumers who want to purchase its products based on personal considerations. 


\section{Cash Waqf}

Word "waqf" etymologically is defined in several meanings. The dictionary of al-Asr defines waqf as to cease and to prevent. Meanwhile, the dictionary of lisan al-Arabi argued that etymologically word "waqf" is in similar meaning to the Arabic word "al-Habs". This word is the form of an infinitive noun which means to hold, to cease, or to be silent (Manzur, 2009). According to Muhammad Ibnu Isma'il in a book titled "Subul as-Salam", waqf means to hold the wealth and take its benefits without spending or undermining the assets and is used in the path of kindness.

Cash waqf is defined as a waqf that is carried out by someone, communities, or legal institutions in the form of cash or other forms of assets like securities (Lubis, 2020). Cash waqf has great potential and an important role in the development of economy. The enormous potential of solicited cash waqf in Indonesia is shown on the following table:

Table 2. Indonesian Waqf Management Profile in the Year of 2018

\begin{tabular}{lc}
\hline \multicolumn{1}{c}{ Waqf Philanthropy } & 20I5-20I8 \\
\hline The Nazhir/ Cash Waqf Managers (based on \\
Badan Wakaf Indonesia data, institutions)
\end{tabular}

Cash waqf is expected to be distributed to all sectors in human lives. The distribution process is an integral part of economic system due to its power to create social justice towards all elements of society. Regardless of the existence of abuse of funds in the distribution process, cash waqf could bring more benefits to human being and fulfil their needs.

Misunderstanding of cash waqf among ordinary people is a factor causing a lack of Muslims' awareness of cash waqf collection. It is occurred due to cash waqf as an Islamic charity form is less promoted by the nazhir and Islamic preachers (Nizar, 20I4).

\section{Wakif Decision}

The consumers, the wakif as well, will consider several factors as a part of decision-making process before deciding whether they should purchase or spend their money on some products and services or not. A decision-making process is a process to select the best alternative that is available in some complicated situation. Several available information will influence the decision-making process as well as the knowledge of products and services (Puspitaningtyas, 2013). 
Many factors are affecting wakif decision to select waqf products promoted by waqf institutions and nazhir. These factors are divided into two forms, internal and external factors. Internal factors consist of indicators on wakif desire in relation with their objectives to obtain continuous reward from God and hope to enter heaven. Other wakif choose to put their money on cash waqf products concerning their intention to worship God.

External factors involve waqf institutions' accountability and transparency, their service quality, promotion factors, and other external factors which influence wakif decision. A wakif decision is in accordance with their interest and consideration. as follows:

With explanation aforementioned, the authors propose several hypotheses in this research paper HI : Religiosity has a positive significant influence on wakif decision to select cash waqf products $\mathrm{H} 2$ : Service quality has a positive significant influence on wakif decision to select cash waqf products

H3 : Trust has a positive significant influence on wakif decision to select cash waqf products

H4 : Promotion has a positive significant influence on wakif decision to select cash waqf products

\section{METHODOLOGY}

This research was a quantitative study that employed a multiple regression analysis with SPSS 2I as the data processing software to seek the influence of wakif preferences on selecting cash waqf in Badan Wakaf Indonesia region of Yogyakarta City.

Populations in this study were all wakif recorded in Badan Wakaf Indonesia region of Yogyakarta City, while the samples were all respondents who hold a cash waqf certificate with a value of more than 500.000 rupiahs. The number of respondents filled in the questionnaire regarding the study is 47 people.

Independent variables in this study were religiosity (XI), service quality (X2), trust (X3), and promotion (X4), while the dependent variable was wakif decision on selecting cash waqf. The equation model for this research was formulated as follows:

$$
Y=\alpha+X 1+X 2+X 3+X 4+\varepsilon
$$

$$
\begin{array}{ll}
\mathrm{Y} & =\text { Wakif decision } \\
\mathrm{XI} & =\text { Religiosity } \\
\mathrm{X} 2 & =\text { Trust } \\
\mathrm{X} 3 & =\text { Service quality } \\
\mathrm{X} 4 & =\text { promotion }
\end{array}
$$

\section{RESULTS AND DISCUSSIONS}

\section{Validity and Reliability Test}

Validity test aims to answer the question regarding the accuracy of information provided by the samples surveyed. Significance level that will be used in this test is $5 \%$. 
Wakif Preferences In Selecting Cash Waqf: A Case of Badan Wakaf Indonesia at Yogyakarta City

Kurniawati Meylianingrum ${ }^{1}$, Muhammad Muhajir Aminy ${ }^{2}$, Mohd. Mizan Aslam³

Table 3. Result of Validity Test

\begin{tabular}{|c|c|c|c|c|}
\hline Variables & Indicators & $\begin{array}{c}\text { Pearson } \\
\text { Correlation } \\
\text { Total }\end{array}$ & r-critical & Status \\
\hline \multirow[t]{10}{*}{ XI } & XI-I & $0.34 \mathrm{I}$ & 0.2876 & Valid \\
\hline & XI-2 & 0.362 & 0.2876 & Valid \\
\hline & XI-3 & $0.34 \mathrm{I}$ & 0.2876 & Valid \\
\hline & XI-4 & 0.498 & 0.2876 & Valid \\
\hline & XI-5 & 0.478 & 0.2876 & Valid \\
\hline & XI-6 & 0.579 & 0.2876 & Valid \\
\hline & XI-7 & 0.591 & 0.2876 & Valid \\
\hline & XI-8 & 0.358 & 0.2876 & Valid \\
\hline & XI-9 & 0.665 & 0.2876 & Valid \\
\hline & XI-IO & 0.626 & 0.2876 & Valid \\
\hline \multirow[t]{10}{*}{$\mathrm{X} 2$} & X2-I & 0.474 & 0.2876 & Valid \\
\hline & $X 2-2$ & 0.435 & 0.2876 & Valid \\
\hline & $X 2-3$ & 0.596 & 0.2876 & Valid \\
\hline & X2-4 & 0.352 & 0.2876 & Valid \\
\hline & $X 2-5$ & 0.634 & 0.2876 & Valid \\
\hline & X2-6 & 0.478 & 0.2876 & Valid \\
\hline & $\times 2-7$ & 0.350 & 0.2876 & Valid \\
\hline & X2-8 & 0.506 & 0.2876 & Valid \\
\hline & X2-9 & 0.370 & 0.2876 & Valid \\
\hline & $\mathrm{X} 2-\mathrm{IO}$ & 0.516 & 0.2876 & Valid \\
\hline \multirow[t]{10}{*}{$\mathrm{X} 3$} & X3-I & 0.366 & 0.2876 & Valid \\
\hline & X3-2 & 0.465 & 0.2876 & Valid \\
\hline & $\mathrm{X} 3-3$ & 0.385 & 0.2876 & Valid \\
\hline & X3-4 & $0.5 \mathrm{I} 3$ & 0.2876 & Valid \\
\hline & $\mathrm{X} 3-5$ & 0.449 & 0.2876 & Valid \\
\hline & $X 3-6$ & 0.366 & 0.2876 & Valid \\
\hline & $\mathrm{X} 3-7$ & 0.435 & 0.2876 & Valid \\
\hline & X3-8 & $0.5 \mathrm{I} 3$ & 0.2876 & Valid \\
\hline & X3-9 & 0.449 & 0.2876 & Valid \\
\hline & $\mathrm{X} 3-\mathrm{IO}$ & 0.616 & 0.2876 & Valid \\
\hline \multirow[t]{6}{*}{$\mathrm{X} 4$} & $\mathrm{X} 4-\mathrm{I}$ & 0.462 & 0.2876 & Valid \\
\hline & $X 4-2$ & 0.485 & 0.2876 & Valid \\
\hline & $X 4-3$ & 0.489 & 0.2876 & Valid \\
\hline & $X 4-4$ & 0.352 & 0.2876 & Valid \\
\hline & $X 4-5$ & 0.492 & 0.2876 & Valid \\
\hline & $X 4-6$ & 0.440 & 0.2876 & Valid \\
\hline
\end{tabular}




\begin{tabular}{|c|c|c|c|c|}
\hline & X4-7 & 0.583 & 0.2876 & Valid \\
& X4-8 & 0.400 & 0.2876 & Valid \\
& X4-9 & 0.365 & 0.2876 & Valid \\
& X4-I0 & 0.516 & 0.2876 & Valid \\
\hline Y & Y-I & 0.315 & 0.2876 & Valid \\
& Y-2 & 0.310 & 0.2876 & Valid \\
& Y-3 & 0.462 & 0.2876 & Valid \\
& Y-4 & 0.485 & 0.2876 & Valid \\
& Y-5 & 0.310 & 0.2876 & Valid \\
& Y-6 & 0.478 & 0.2876 & Valid \\
& Y-7 & 0.579 & 0.2876 & Valid \\
& Y-8 & $0.59 I$ & 0.2876 & Valid \\
& Y-9 & 0.558 & 0.2876 & Valid \\
& Y-I0 & 0.466 & 0.2876 & Valid \\
\hline
\end{tabular}

An instrument is able to become a valid data by consulting and looking at the number of $r-$ observation found in r-product moment table based on significance level of $5 \%$. If r-observation $<\mathrm{r}$ table, the data is invalid. Otherwise, if r-observation $>$ r-table, the data becomes valid. All of $r-$ observation in this research $>\mathrm{r}$-table, thus all the indicators used could be categorized as valid data.

Table 4. Result of Reliability Test

\begin{tabular}{|c|c|}
\hline Cronbach's Alpha & N of Items \\
\hline 0,935 & 50 \\
\hline
\end{tabular}

The table above showed a value of cronbach's alpha of $0,935(>0,6)$ which means the questionnaires used in this study is reliable and consistent.

\section{Multiple Regression Analysis}

The authors used a multiple regression analysis to seek a relationship between observed independent variables (religiosity, service quality, trust, and promotion) with dependent variables (wakif decision on cash waqf). The finding in this research was given in the following table:

Table 5. The Result of Multiple Regression Analysis

\begin{tabular}{|c|c|c|c|c|c|c|c|}
\hline \multirow[t]{2}{*}{ Model } & \multicolumn{2}{|c|}{$\begin{array}{l}\text { Unstandardised } \\
\text { Coefficients }\end{array}$} & \multirow{2}{*}{$\begin{array}{l}\text { Standardised } \\
\text { Coefficients }\end{array}$} & \multirow[t]{2}{*}{$\mathrm{T}$} & \multirow[t]{2}{*}{ Sig. } & \multicolumn{2}{|c|}{ Collinearity Statistics } \\
\hline & $\mathrm{B}$ & $\begin{array}{l}\text { Std. } \\
\text { Error }\end{array}$ & & & & Tolerance & VIF \\
\hline (Constant) & 7,773 & 2,644 & & 2,939 & 0,005 & & \\
\hline XI & 0,199 & 0,076 & 0,229 & 2,625 & 0,012 & 0,390 & 2,566 \\
\hline
\end{tabular}




\begin{tabular}{|l|l|l|l|l|l|l|l|}
\hline $\mathrm{X} 2$ & 0,249 & 0,093 & 0,284 & 2,687 & $0,0 \mathrm{IO}$ & 0,266 & 3,756 \\
$\mathrm{X} 3$ & $0,2 \mathrm{I} 9$ & 0,084 & 0,255 & $2,6 \mathrm{I} 2$ & $0,0 \mathrm{I} 2$ & $0,3 \mathrm{II}$ & $3,2 \mathrm{I} 6$ \\
$\mathrm{X} 4$ & 0,186 & 0,080 & 0,274 & 2,339 & 0,024 & $0,2 \mathrm{I} 7$ & $4,6 \mathrm{I3}$ \\
\hline
\end{tabular}

a. Dependent Variable: Y

A mathematical equation that could be constructed based on Table I is as follows:

$$
Y=7,773+0,199 X_{1}+0,249 X_{2}+0,219 X_{3}+0,186 X_{4}
$$

The mathematical equation above could be explained in these following points:

I. A constanta of 7.773 represented the value of wakif decision in Badan Wakaf Indonesia region of Yogyakarta City with assumption that all independent variables (religiosity, trust, service quality, and promotion factor) value is 0 .

2. XI value of 0.199 indicated a positive impact of religiosity on wakif decision. It was concluded that a better value of wakif religiosity would increase wakif decision level on cash waqf selection in Badan Wakaf Indonesia region of Yogyakarta City, and vice versa.

3. $\mathrm{X} 2$ value of 0.249 showed a positive influence of trust on wakif decision. It was concluded that a better value of trust on waqf institutions' accountability and transparency would drive a better wakif decision level on cash waqf selection in Badan Wakaf Indonesia region of Yogyakarta City, and vice versa.

4. $\mathrm{X} 3$ value of 0.219 indicated a positive effect of waqf institutions' service quality on wakif decision. It was concluded that the better service quality, the higher wakif decision level on cash waqf selection in Badan Wakaf Indonesia region of Yogyakarta City, and vice versa.

5. X4 value of 0.186 showed a positive impact of promotion on wakif decision. It was concluded that more promotion carried out by waqf institutions would encourage wakif to select cash waqf in Badan Wakaf Indonesia region of Yogyakarta City and vice versa.

The value of R-Squared or Adjusted R-Squared is translated as an indicator of independent variables' contribution level on dependent variables. It is ranging from 0 to $\mathrm{I}$. The bigger the value is, the more significant the influence of all independent variables on dependent variables will be.

Table 6. Model Summary

\begin{tabular}{|c|c|c|c|c|}
\hline Model & $\mathrm{R}$ & $\mathrm{R}$ Squared & $\begin{array}{c}\text { Adjusted R } \\
\text { Squared }\end{array}$ & $\begin{array}{c}\text { Std. Error of the } \\
\text { Estimate }\end{array}$ \\
\hline $\mathrm{I}$ & 0,936 & 0,875 & 0,863 & $\mathrm{I}, 092 \mathrm{I} 4$ \\
\hline
\end{tabular}

The value of Adjusted R-Squared $0.863(86,3 \%)$ indicated a considerable contribution of all independent variables (religiosity, trust, service quality, and promotion) on wakif decision to select cash waqf in Badan Wakaf Indonesia region of Yogyakarta City. 
Table 7. ANOVA

\begin{tabular}{|c|c|c|c|c|c|}
\hline Model & $\begin{array}{l}\text { Sum of } \\
\text { Squares }\end{array}$ & Df & Mean Square & F & Sig. \\
\hline Regression & 351,308 & 4 & 87,827 & \multirow[t]{3}{*}{73,632} & \multirow[t]{3}{*}{0,000} \\
\hline I Residual & 50,097 & 42 & $\mathrm{I}, \mathrm{I} 93$ & & \\
\hline Total & 401,404 & 46 & & & \\
\hline
\end{tabular}

a. Dependent Variable: Y

b. Predictors: (Constant), X4, XI, X3, X2

The value of Sig. F of 0.000 and less than 0.05 indicated that all independent variables (religiosity, trust, service quality, and promotion) simultaneously influenced the observed dependent variable, namely wakif decision.

\section{Hypotheses Test}

Table 8. t-Test Result

\begin{tabular}{|c|c|c|c|c|c|c|}
\hline \multirow{2}{*}{\multicolumn{2}{|c|}{ Model }} & \multicolumn{2}{|c|}{ Unstandardised Coefficients } & Standardised & \multirow[t]{2}{*}{$\mathrm{t}$} & \multirow[t]{2}{*}{ Sig. } \\
\hline & & B & Std. Error & Beta & & \\
\hline \multirow{5}{*}{ I } & (Constant) & 7,773 & 2,644 & & 2,939 & 0,005 \\
\hline & XI & 0,199 & 0,076 & 0,229 & 2,625 & 0,012 \\
\hline & $\mathrm{X} 2$ & 0,249 & 0,093 & 0,284 & 2,687 & 0,010 \\
\hline & X3 & 0,219 & 0,084 & 0,255 & $2,6 \mathrm{I} 2$ & 0,012 \\
\hline & $\mathrm{X} 4$ & 0,186 & 0,080 & 0,274 & 2,339 & 0,024 \\
\hline
\end{tabular}

\section{The Impact of Religiosity on Wakif Decision (HI)}

HI in this study was a variable named religiosity that has a positive significant influence on wakif decision to select cash waqf. According to the data processing result in Table 3, religiosity variable had a positive significant impact on wakif decision. It was proven by the value of coefficients 0.199 (XI) and the value of Sig. t 0.012 (less than 0.05).

Religiosity inserts religious norms into individuals lives. The norms become a guide to live and to behave in the world. Religious is a motivational element driving a person to carry out all their activities and to make those activities as a worship form to God. Religiosity makes someone becoming an obedient person. In a religious person's perspective, all good activities are perceived as a worship form and are valued with reward that will bring them into the paradise.

Giving waqf as a charity is not one of the pillars of Islam. However, waqf is a worship instrument that is preferable (sunnah) to carry out in the religion of Islam. 


\section{The Impact of Trust on Wakif Decision (H2)}

$\mathrm{H} 2$ in this study was a variable named trust that has a positive significant influence on wakif decision to select cash waqf. Based on the result of data analysis aforementioned, a variable of trust has a positive significant impact on wakif decision. It was proven by the value of 0.249 (X2) and the value of Sig. t 0.0I0 (less than 0.05).

Wakif s trust is based on their trust level toward waqf institutions. Waqf institutions and nazhir had eventually given an effort at their best on cash waqf managing and transparency of waqf institutions' annual financial reporting as well.

The board of decision-makers in any NGO should be responsible to the environment, society, and any related institutions. The accountability of waqf institutions is enhanced when societies have a big trust in what they are working on. Social programs that a waqf institution carried out will increase people's trust level, particularly wakif in their works.

\section{The Impact of Service Quality on Wakif Decision (H3)}

$\mathrm{H} 3$ in this study was a variable named service quality that influences positively wakif decision to select cash waqf. Based on the result of data analysis, it is concluded that the observed independent variable has a positive significant impact on the dependent variable. It was proven by the value of 0.219 (X3) and the value of Sig. t 0.0I2 (below 0.05).

The employee of Badan Wakaf Indonesia region of Yogyakarta City has served their wakif at their best. This service cannot be separated with three main and important components: employee's attitudes, skills, and knowledge. Excellent service quality will effect on the consumer's satisfaction. In this study, it can be concluded that excellent service quality will impact on the wakif s satisfaction, which in its turn will also influence their interest to distribute their cash waqf through Badan Wakaf Indonesia region of Yogyakarta City.

\section{The Impact of Promotion on Wakif Decision (H4)}

$\mathrm{H} 4$ in this study was a promotion as the independent variable that has a positive significant impact on wakif decision to select cash waqf. Based on the data analysis result, the value of 0.186 (X4) and the value of Sig. t 0.024 (below 0.05 ) proved that promotion variable has a positive significant impact on wakif s decision to select cash waqf in Badan Wakaf Indonesia region of Yogyakarta City.

Promotion is an important factor in attracting the consumer's interest to select a company's products or services. In this case, an excellent promotion from Badan Wakaf Indonesia region of Yogyakarta City will attract wakifs interest to select cash waqf as an alternative to devote their money to obtain ceaseless compensation from God.

\section{Cash Waqf Management in Badan Wakaf Indonesia region of Yogyakarta City}

Badan Wakaf Indonesia is a Yogyakarta City-based waqf institution. This waqf institution indirectly solicits and distributes waqf funds through their waqf managers called as nazhir who have been allowed and being under the supervision of Badan Wakaf Indonesia. The main duties of Badan Wakaf Indonesia are to give instruction and insight to all its nazhir in term of collecting, managing, and distributing waqf funds to society. 
BMT Bina Ihsanul Fikri that is one of Badan Wakaf Indonesia's nazhir employes two approaches, namely productive and non-productive approach, to manage waqf funds from Muslims in Yogyakarta City. BMT Bina Ihsanul Fikri itself manages a productive cash waqf by purchasing Islamic stock inside the market. The dividend from this Islamic financial instrument is allocated for productive activities. At the same time, a non-productive cash waqf is managed by allocating waqf funds to establish an orphanage "Panti Asuhan Yatim Dhuafa al-Amin Muhammadiyyah" that is under BMT Bina Ihsanul Fikri supervision.

The management of Dewan Masjid Indonesia, a Badan Wakaf Indonesia's nazhir, is similar to BMT Bina Ihsanul Fikri. Cash waqf collected in this nazhir is divided into two categories as well, productive and non-productive cash waqf. Productive cash waqf is managed productively by Bank BPD DIY Syariah and is distributed in the form of Islamic bank's financing. Profit from this Islamic bank's activity is allocated to help the orphanage and to empower mosques around the Special Region of Yogyakarta. At the same time, a non-productive cash waqf is allocated for mosques' management, and to purchase an ambulance car for people's health needs. Dewan Masjid Indonesia is frequently promoting cash waqf product amongst society through a monthly-published book, and Islamic teachings carried out by local Muslim preachers as well.

\section{E. CONCLUSION}

This study was a quantitative-based research involving independent and dependent variables to calculate and to predict the influence between both variables. The findings in this research showed a positive significant impact of all observed independent variables namely religiosity, trust, service quality, and promotion factor toward wakif decision to select cash waqf in Badan Wakaf Indonesia region of Yogyakarta City.

Another findings in this study investigated a cash waqf management that is applied in the waqf institution. The nazhir or waqf managers have an official duty from Badan Wakaf Indonesia to collect and to distribute cash waqf in the region. Badan Wakaf Indonesia as the waqf institution only supervised and gave instruction to the nazhir regarding cash waqf management. There are five nazhirs under the supervision of Badan Wakaf Indonesia region of Yogyakarta City: Badan Wakaf Uang Tunai Majelis Ulama Indonesia (BWUT-MUI), Dewan Masjid Indonesia (DMI), KJKS BMT Beringharjo, KSP BMT Al-Ikhlas, and BMI BMT Bina Ihsanul Fikri. 


\section{REFERENCES}

.Ab Rahman, A. (2009). Peranan wakaf dalam pembangunan ekonomi umat Islam dan aplikasinya di Malaysia. Jurnal Syariah, I7(I), II3-152.

Al Arif, M. N. R. (20I2). Wakaf uang dan pengaruhnya terhadap program pengentasan kemiskinan di Indonesia. Jurnal Indo-Islamika, 2(I), I7-29.

Aziz, M. (2017). Peran Badan Wakaf Indonesia (BWI) dalam mengembangkan prospek wakaf uang di Indonesia. JES (Jurnal Ekonomi Syariah), I(2).

Bayne, R. (2015). Membaca Kepribadian untuk Konselor: Memahami Preferensi, Motivasi dan Riwayat Hidup. Yogyakarta: Pustaka Pelajar.

Chrysanthini, B., Sumarwan, U., \& Rifin, A. (2018). Preferensi Konsumen terhadap Produk Sayuran Organik (Studi Kasus Konsumen UD Fabela-Myfarm) di Bogor Jawa Barat. MANAJEMEN IKM: Jurnal Manajemen Pengembangan Industri Kecil Menengah, I2(2), I5I.

Dewi, W. S., Hasiolan, L. B., \& Minarsih, M. M. (2016). Pengaruh Kualitas Produk, Kepercayaan Terhadap Keputusan Pembelian Dengan Kepuasan Konsumen Sebagai Variabel Intervening. Journal of Management, 2(2), I-I9.

Fahrudin, M. F., \& Yulianti, E. (20I5). layanan terhadap keputusan pembelian nasabah Bank Mandiri Surabaya. Pengaruh Promosi, Lokasi, Dan Kualitas Layanan Terhadap Keputusan Pembelian Nasabah Bank Mandiri Surabaya. 5(I), I-I4. Https://Doi.Org/IO.I44I4/Jbb.V5iI.385.

Fitriyah, F. (2016). Pengaruh Pendapatan, Dana Talangan Haji Dan Religiusitas Terhadap Keputusan Nasabah Mendaftar Haji (Studi Pada Bni Syariah Tulungagung) Faridatul. Jurnal Nusamba, I(I), $58-67$.

Hasan, S. (2010). Wakaf Uang Dan Implementasinya Di Indonesia. Journal de Jure, 2(2), I62-I77. Husein, U. (2008). Desain Penelitian Akuntansi Keperilakuan. Jakarta: Raja Grafindo Persada.

Kotler, P., \& Keller, K. L. (2009). Manajemen Pemasaran. Jakarta: Erlangga.

Linley, P. A. (2008). Average to A. Realising strengths in yourself and others. Kanada: CAPP Press, Converty.

Lubis, H. (2020). Potensi dan Strategi Pengembangan Wakaf Uang di Indonesia. I(I), 43-59.

Maisur, Arifin, M. arfan, \& M. S. (20I5). Pengaruh Prinsip Bagi Hasil, Tingkat Pendapatan,

Religiusitas Dan Kualitas Pelayanan Terhadap Keputusan Menabung Nasabah Pada Bank Syariah di Banda Aceh. Jurnal Magister Akuntansi Pascasarjana, 4(2), I-8. Retrieved from Http://Www.Jurnal.Unsyiah.Ac.Id/JAA/Article/View/4460.

Marthon, P., \& Papaix, P. (2008). SISYPHE-An Integrated Development Environment for System Designing and Performing Simulations.

Murti, I., \& Santika, I. (2016). Pengaruh Kepercayaan Nasabah, Bauran Produk Dan Bauran Lokasi Terhadap Transaksi Nasabah. E-Jurnal Manajemen Universitas Udayana, 5(I), 253805.

Nizar, A. (2014). Faktor-Faktor Yang Mempengaruhi Persepsi Wakif Tentang Wakaf Uang. Esensi: Jurnal Bisnis Dan Manajemen, 4(I), 2I-36.

Nurlaeli, I. (2017). Pengaruh Faktor Budaya, Psikologi, Pelayanan, Promosi dan Pengetahuan tentang Produk terhadap Keputusan Nasabah Memilih BPRS di Banyumas. Islamadina, I8(2), 75. https://doi.org/IO.30595/islamadina.vI8i2.1922.

Pratiwi, N., \& Seminari, N. (2015). Pengaruh Kualitas Pelayanan, Kepercayaan Dan Nilai Nasabah 
IKONOMIKA

Volume 5, No I (2020)

Terhadap Kepuasan Nasabah. E-Jurnal Manajemen Universitas Udayana, 4(5), 252927.

Puspitaningtyas, Z. (2013). Perilaku Investor Dalam Pengambilan Keputusan Investasi di Pasar Modal, Forum Manajemen Indonesia.

Rahayu, E. (2018). Pengaruh Lokasi, Kelengkapan Produk, dan Pelayanan Terhadap Keputusan Pembelian Konsumen pada Imam Market Kisaran. 4307(February), 7-I2.

Romdhoni, A. H., Ratnasari, D. (2018). Pengaruh Pengetahuan, Kualitas Pelayanan, Produk, dan Religiusitas Terhadap Minat Nasabah Untuk Menggunakan Produk Simpanan Pada Lembaga Keuangan Mikro Syariah, Jurnal Ilmiah Ekonomi Islam, 4(02), I360I47.

Sarwita, A. (2019). Pengaruh Kualitas Pelayanan dan Promosi Terhadap Keputusan Nasabah Untuk Menabung. MAKSI Jurnal Ilmiah Manajemen \& Akuntansi, 4. https://doi.org/I0.5040/9781350I22741.100I467.

Sumarwan, U., Noviandi, A., \& K. (2013). Analisis Proses Keputusan Pembelian, Persepsi dan Sikap Konsumen Terhadap Beras Organik di Jabotabek. Pangan, 22, 333-344.

Tajudin, M. H., \& Mulazid, A. S. (2017). Pengaruh Promosi, Kepercayaan Dan Kesadaran Merek Terhadap Keputusan Nasabah Menggunakan Produk Tabungan Haji (Mabrur) Bank Syariah Mandiri Kcp. Sawangan Kota Depok. ISLAMICONOMIC: Jurnal Ekonomi Islam, 8(I), I9-46. https://doi.org/I0.32678/ijei.v8iI.64.

Tumbelaka, A., Kindangen, P., \& Kalangi, J. A. F. (2019). Preferensi Konsumen Dalam Memilih Bank BRI dan Bank BCA Di Manado Berdasarkan Kualitas Pelayanan. Jurnal Administrasi Bisnis, 9(I), IO.

Yulianti, R., Sangen, M., \& Rifani, A. (2016). Pengaruh Nilai-Nilai Agama, Kualitas Layanan, Promosi, dan Kepercayaan terhadap Keputusan menjadi Nasabah Bank Syariah di Banjarmasin. Jurnal Wawasan Manajemen, 4(2), I30. 
Wakif Preferences In Selecting Cash Waqf: A Case of Badan Wakaf Indonesia at Yogyakarta City Kurniawati Meylianingrum ${ }^{1}$, Muhammad Muhajir Aminy' ${ }^{2}$, Mohd. Mizan Aslam ${ }^{3}$ 